\title{
Do Managerial Objectives Drive Bad Acquisitions?
}

\section{Citation}

Morck, Randall, Andrei Shleifer, and Robert W. Vishny. 1990. “Do Managerial Objectives Drive Bad Acquisitions?" The Journal of Finance 45 (1) (March): 31. doi:10.2307/2328808. http:// dx.doi.org/10.2307/2328808.

\section{Published Version}

doi: $10.2307 / 2328808$

\section{Permanent link}

http://nrs.harvard.edu/urn-3:HUL.InstRepos:27693803

\section{Terms of Use}

This article was downloaded from Harvard University's DASH repository, and is made available under the terms and conditions applicable to Other Posted Material, as set forth at http:// nrs.harvard.edu/urn-3:HUL.InstRepos:dash.current.terms-of-use\#LAA

\section{Share Your Story}

The Harvard community has made this article openly available.

Please share how this access benefits you. Submit a story.

Accessibility 


\title{
NBER WORKING PAFER SERIES
}

DO MANAGERIAL OBJECTIVES DRIVE BAD ACQUISITIONS?

\author{
Randa11 Morck
}

Andrei Shleifer

Robert W. Vishny

Working Paper No. 3000

\author{
NATIONAL BUREAU OF ECONOMIC RESEARCH \\ 1050 Massachusetts Avenue \\ Cambridge, MA 02138 \\ June 1939
}

We are indebted for comments to Steve Kaplan and Sam Peltzman, and for financial support to the Russell Sage Foundation, the Center for the Study of the Economy and the State, the William S. Fishman and the Dimensional Fund Advisers Faculty Research Funds at the Graduate School of Business, University of Chicago. This paper is part of NBER's research program in Financial Markets and Monetary Economics. Any opinions expressed are those of the author not those of the National Bureau of Economic Research. 
NBER Working Paper \#3000

June 1989

DO MANAGERIAL OBJECTIVES DRIVE BAD ACQUISITIONS?

\section{ABSTRACT}

This paper documents for a sample of 327 US acquisitions between 1975 and 1987 three forces that systematically reduce the announcement day return of bidding firms. The returns to bidding shareholders are lower when their firm diversifies, when it buys a rapidly growing target, and when the performance of its managers has been poor before the acquisition. These results are consistent with the proposition that managerial rather than shareholders' objectives drive bad acquisitions.

Randa11 Morck

Faculty of Business

University of Alberta

Edmonton Alberta

Canada
Andrei Shleifer

Graduate School of Business

University of Chicago

1101 E. 58th street

Chicago, IL 60637
Robert W. Vishny Graduate School of Business University of Chicago Chicago, IL 60637 
1. Introduction.

There is now considerable evidence that making acquisitions is a mixed. blessing for shareholders of acquiring companies. Average returns to bidding shareholders from making acquisitions are at best slightly positive, and significantly negative in some studies (Bradley, Desal and KIm 1988, Roll 1986). Some have suggested that negative bidder returns are purely a consequence of stock financing of acquisitions that leads to a release of adverse information about acquiring firms (Asquith, Brunner, and Mullins 1986). In this case, negative bidder returns are not evidence of a bad investment. An alternative interpretation of poor bidder performance is that bidding firms overpay for the acquisitions they make. In this paper, we present evidence that some types of bidders systematically overpay.

There are at least two reasons why bidding firms' managers might overpay In acquisitions, thereby truly reducing the wealth of their shareholders as opposed to just revealing bad news about their firm. According to Roll (1986), managers of bidding flrms are infected by hubris, and so overpay for targets because they overestimate their own abllity to run them. Another view of overpayment is that managers of bidding firms pursue personal objectives other than maximization of shareholder value. To the extent that acquisitions serve these objectives, wanagers of bidding firms are willing to pay more for targets than they are worth to bidding firms' shareholders.

In this paper, we try to find out which acquisitions are bad investments for bidding shareholders but can be good for bidding managers. We focus on two aspects of acquisition strategies that can be readily understood in terms of managerlal objectives: buying growth and diversification. We also look at the relationship between bidders' past performance and their returns from acquisitions. This relationship sheds light on the bidding managers' motives 
for acquiring. Before presenting the evidence, we briefly summarize the theoretical arguments for looking at relatedness, target growth and past performance of the bidder to uncover managerial objectives in acquisitions.

RELATEDNESS: Several models predict that managers would pursue unrelated diversification even when it hurts shareholders. First, if managers themselves are not properly diversified, they would diversify the holdings of the firm to reduce their personal risk (Amihud and Lev 1981). Second, to assure the survival and continuity of the firm even when value maximization dictates shrinkage or liquidation, managers would try to enter new lines of business. Third, when poor performance of the firm threatens a manager's job, he has an incentive to enter new businesses that he might be better at. In all these cases, managers might be willing to overpay for targets outside the bidding firm's industry, reducing the wealth of their shareholders.

BUYING GROWTH: Several models predict that managers want their firms to grow even at a cost to market value. Baumol (1959) simply assumes that growth of sales is part of the manager's utility function. Donaldson (1984) suggests that growth of the firm creates attractive promotion opportunities for its junior managers, enabling the firm to attract young managers concerned with upward mobility. By buying a growing firm, a mature firm ensures that its younger managers do not have to compete for only a few top positions. Growth of this sort can be value maximizing if it serves to attract and retain required managerial talent. It can also be wasteful if managers overpay for growing targets just to promote their proteges. Finally, pursuit of growth can be part of a strategy of ensuring long run 
survival of the corporation as an independent entity (Donaldson and Lorsch 1983), a goal likely to be more important to managers than to shareholders.

On these views, managers maximlze growth, and not just pure size, to create attractive opportunities for the Insiders and to assure the survival of the firm. Managers spend corporate resources to buy rapidly growing firms, even if such investments have a negative present value.

PAST PERFORMANCE OF ACOUIRER MANAGEMENT: Poor managers might make poor acquisitions simply because they are poor at everything. Alternatively, poor managers have more incentive to acquire to assure the survival of the firm or to find new businesses they might be good at. The prediction is that acquisitions by poor managers are particularly disastrous. In contrast, a plausible version of Roll's hubris hypothesis predicts that the worst acquisitions are made by well performing firms, since thelr managers are most likely to be infected by hubris.

Our evidence suggests that bad acquisitions are driven by managerial objectives; they are not just cases of information release or of hubris of successful managers. We find that unrelated diversification and buying growth reduce the returns to making an acquisition. We also find that bad managers are also bad acquirers, consistent with the notion that poor performance drives managers to try something new. Finally, we find that the market penalizes unrelated diversification much more heavily in the 1980 s than in the 1970s, colncident with the rise of hostile bust-up takeovers.

These results fit well with some recent findings of others.. Lang, Stulz and Walkling (1988) find that having a low Tobin's $Q$, which might stand for poor quality of the bidding firm's management, reduces a bidder's return in a 
takeover. They also find that a low Tobin's $Q$ of the target, which is likely to be correlated with low sales growth, is associated with a higher bidder return. The latter finding is also obtained by Servaes (1988). Lewellen, Loderer and Rosenfeld (1985) and You, Caves, Henry and Smith (1986) show that low management ownership in the bidding firm is associated with lower returns from making acquisitions. This result suggests that managers who have little incentive to maximize market value nake bad acquisitions. In a similar vein, Stulz, Walkling and Song (1988) find that the bidder's share of total takeover gains rises with bidder's management ownership stake. Mitchell and Lehn (1988) find that firms making acquisitions that reduce their market value are subsequently much more likely to be acquired than firms not making bad acquisitions. Although neither these papers nor our own work identify managerial objectives precisely, the importance of these objectives in determining acquisition choices seems well supported.

Section 2 of the paper describes the data we use in the analysis. Sections 3 and 4 present our empirical results. Section 5 concludes.

2. The Sample and Construction of Variables.

The Sample: Our data set is obtained by combining Bronwyn Hall's (1988) sample of mergers based on deletions of firms from Compustat with Jarrell and Poulsen's (1988) merger sample. We only consider acquisitions in which the bidder has actually obtained control. Table 1 presents the details of sample construction. The main reasons we lose observations include unavailability of stock price data on CRSP, absence of data in COMPUSTAT needed to construct our bidder performance variables, and missing data in the Dun and Bradstreet Million Dollar Directory (MDD) on the lines of business each firm operates 


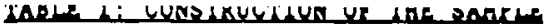

PAYEL A: CONSTRUCTION OP THE BASIC FOLL SAMPLE

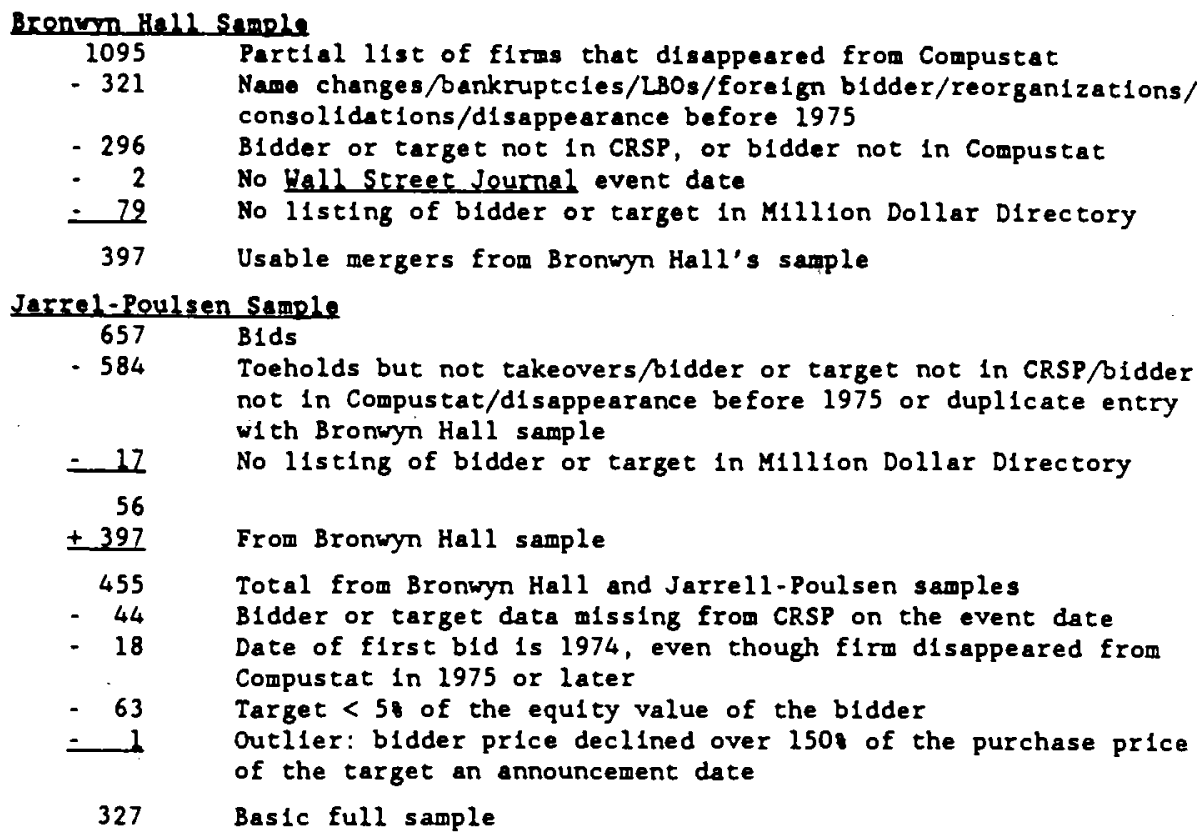

PANEL B : CONSTROCTION OF MORE RESTRICTED SAMPLE POR EMPIRICAL WORK

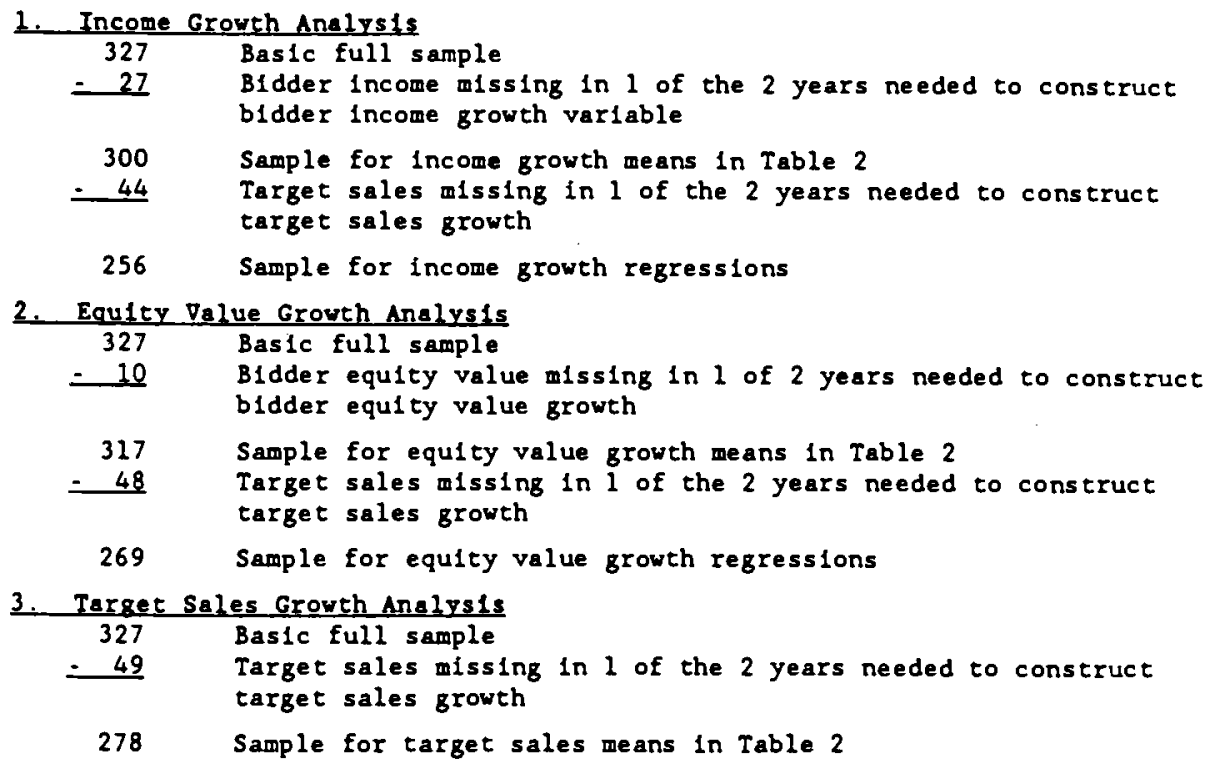


in. We use these lines of business to construct our diversification measures. We also onit 63 observations because the equity value of the target is less than 5 of the equity value of the bidder. These observations would only add noise to the results. Finally, we omit one outlier firm whose market value dropped more than 1508 of the price it paid for the acquisition. Table 1 shows that our full sample consists of 327 acquisitions.

Return Variable: The traditional measure of the bidder's payoff from making an acquisition is the percentage change in the bidder's equity value at or around the time the acquisition is announced. This measure is unsatisfactory because it makes equally good acquisitions differentially good to firms of different sizes. When a firm with an equity value of $\$ 1000$ buys another firm for $\$ 200$ and as a result loses $\$ 50$ in equity value, its return is $-5 \%$. But when a firm with an equity value of $\$ 500$ makes the very same acquisition for $\$ 200$ and loses $\$ 50$ in equity value, its return is -108 . In this calculation, the same poor investment is evaluated differently depending on the initial equity value of the bidding firm. A good return measure should make the quality of the investment independent of the equity value or other characteristics of the bidding firm.

A measure not suffering from this problem is the ratio of the change in the market value of the bidder to the acquisition price of the target. This variable is equal to the ratio of the acquisition's net present value to its price. This measure is obviously $-25 \%$ in both cases mentioned above. Using the price paid for the target as the norwalizing factor seems more natural than using the initial market value of the bidder.

We use the date on which the acquirer's first bid is announced in the Wall street Journal as our event date. We then compute the change of the bidder's equity value from two trading days before to one trading day after 
the event date. We calculate the acquisition price by looking at the equity value of the target on the first trading day following the last bid mentioned In the Wall Street Journal. Our return variable is then the ratio of the change in the bidder equity value to the acquisition price.

Relatedness Measures: One of the main issues addressed in this paper is the relative attractiveness of related and unrelated acquisitions. We construct two measures of relatedness. The first measures whether the target has any lines of business in common with the bidder. For each target and bidder in the sample, we use the Dun and Bradstreet Million Dollar Directory (MDD) to obtain the 4-digit SIC codes of the three main lines of business (by sales) that the firm operates $\mathrm{in}^{1}$. If the firm operates in fewer than three 4-digit industries, we use all lts industries. All the data are for the year prior to the acquisition. If the bidder and the target have a 4-digit Industry in common among the top three they operate in, we call the acquisition related. Otherwise we call the acquisition unrelated. This procedure leaves us reasonably confident that a related acquisition really falls in the firm's field of expertise ${ }^{2}$.

The second measure of relatedness is the correlation coefficient of monthly stock returns between the target and the bidder over the three years prior to the acquisition. The data are taken from both the NYSE/AMEX and the OTC files of CRSP. Although this variable is highly correlated with the previous measure, it is perhaps better for asking whether managers make acquisitions to diversify elther their personal risk or the firm's risk.

$1_{\text {SIC }}$ code 6711 , used for holding companies, is not treated as a separate line of business.

${ }^{2}$ We have also conducted the analysis using 2-digit SIC codes to measure relatedness. Not surprisingly, the difference between related and unrelated acquisitions is much smaller in this case. 
Target Growth Measure: To evaluate the value consequences of buying growing firms, we must measure the growth rate of the target. We use the total growth rate of sales between 5 years before the acquisition and the year before, defined as $\log (S(t-1))-\log (S(t-6))$, where $t$ is the year of the acquisition, and $S(x)$ is sales in year $x$ from COMPUSTAT.

Measures of Past Performance of the Bidder: We use two measures of the past performance of the bidding firm: one based on growth of the value of the equity and one based on growth of income. We use the firm's performance relative to its industry because the industry component of performance is presumably not under the management's control. Use of industry-adjusted performance to measure the quality of management is supported by the finding that firms underperforming their industries have high internally-precipitated management turnover (Morck, Shleifer and Vishny 1989).

Our measure of the bidding firm's industry-adjusted equity value growth is the difference between the three year growth of the equity value of the bidder and the three year growth of the equity value of its "industry." Three-year equity value growth is defined as $\log (V(t-1))-\log (V(t-4))$, where $t$ is the year of the acquisition and $V(x)$ is the value of equity at the end of year $x$ from COMPUSTAT. To define the equity value growth of the bidder's industry, we use the top three 4-digit SIC codes that the bidder operates in, discussed above. For each code, we take up to 10 other firms operating in the same 4-digit SIC code, making sure that for each of these firms this SIC code is one of its two most important in terms of sales. We take 10 firms in alphabetical order from the list of firms operating in each 4-digit SIC code that the MDD provides. When there are fewer than 10 firms, we take all the ones the MDD offers. When a firm does not have equity value data going four years back, we take a substitute that does. Using this procedure, we can 
construct the 3 -year equally welghted equity value growth rate for each 4digit Industry that each bidder operates in. Last, we take the simple arithmetic average of the 3-year growth rates of the top three 4-digit industrles that each bidder operates in to arrive at the equity growth rate of the bidder's "industry."

An exactly parallel procedure gives us 3 -year bidder income growth rate relative to industry. We use income growth rates between years -4 and -1 , where income is defined as the sum of net income, interest and deferred taxes taken from COMPUSTAT.

Other Varlables Used in the Analysis: We use two other variables in the analysis. First, we use a dummy variable equal to 1 when multiple bidders are involved in the contest, since it has been documented that bidders do worse when they are involved in an open contest for the target (Bradley, Desai and Kim 1988). Second, we examine whether the returns to bidders in related and unrelated acquisitions have changed in the 1980s. At least two changes have occurred under the Reagan administration. First, the antitrust policy has become laxer, presumably ralsing the returns to related diversification by allowing some extremely profitable matches to occur. Second, investors have apparently become disillusioned with unrelated diversification, which has led to the advent of hostile bustup takeovers.

3. Preliminary evidence.

In this section, we present some simple statistics on bidder returns in acquisitions. In the next section, we present the regressions.

Recall that we define the bidder return as the ratio of the 3 -day change in the bidding firm's equity value around the announcement date to the price 
paid for the target's equity. The mean value of bidder return in the 329 acquisitions is $-.65 \%$, with a standard error of $1.39 \% ; 41.68$ of the returns are positive. Hereafter we use the notation $-.658(1.39, .416>0)$. Although we define the bidder return variable differently from previous studies, the common finding that the average bidder return is not significantly different from 0 obtains in our data set as well. The question 1s: which properties of the match make this return (more) negative? The three properties we look at are the growth rate of the target, the past performance of the bidding firm, and relatedness of the acquisition. Table 2 presents mean bidder returns for varlous categories of flrms, as well as ttests of the difference in means across categories and chi-squared tests of the difference in percent positive.

To examine the effects of the growth rate of target's sales, we divide the sample into faster than the median and slower than the median growing targets. For fast growing targets, the mean bidder return is -3.538 (2.39, $.388>0$ ). For slow growing targets, the mean bidder return is 2.988 (1.95, $.460>0$ ). Although neither mean is significantly different from 0 , their difference, equal to 6.518 , is significantly positive $(t-2.11)$. Buying a fast growing company is unattractive relative to buying a slow growing one. Recall that we measure the quality of bidding firm's management in two distinct ways: 3 -year equity value growth relative to industry and 3-year income growth rate relative to industry. For both income and equity value, we split the sample into firms that grow faster than their industry and firms that grow slower than their industry. Bidders with fast relative equity growth earn an average return of $3.778(2.26, .474>0)$. Bidders with slow relative equity growth earn an average return of $-4.948(1.71, .354>0)$. According to this measure, bad managers earn significantly negative returns 

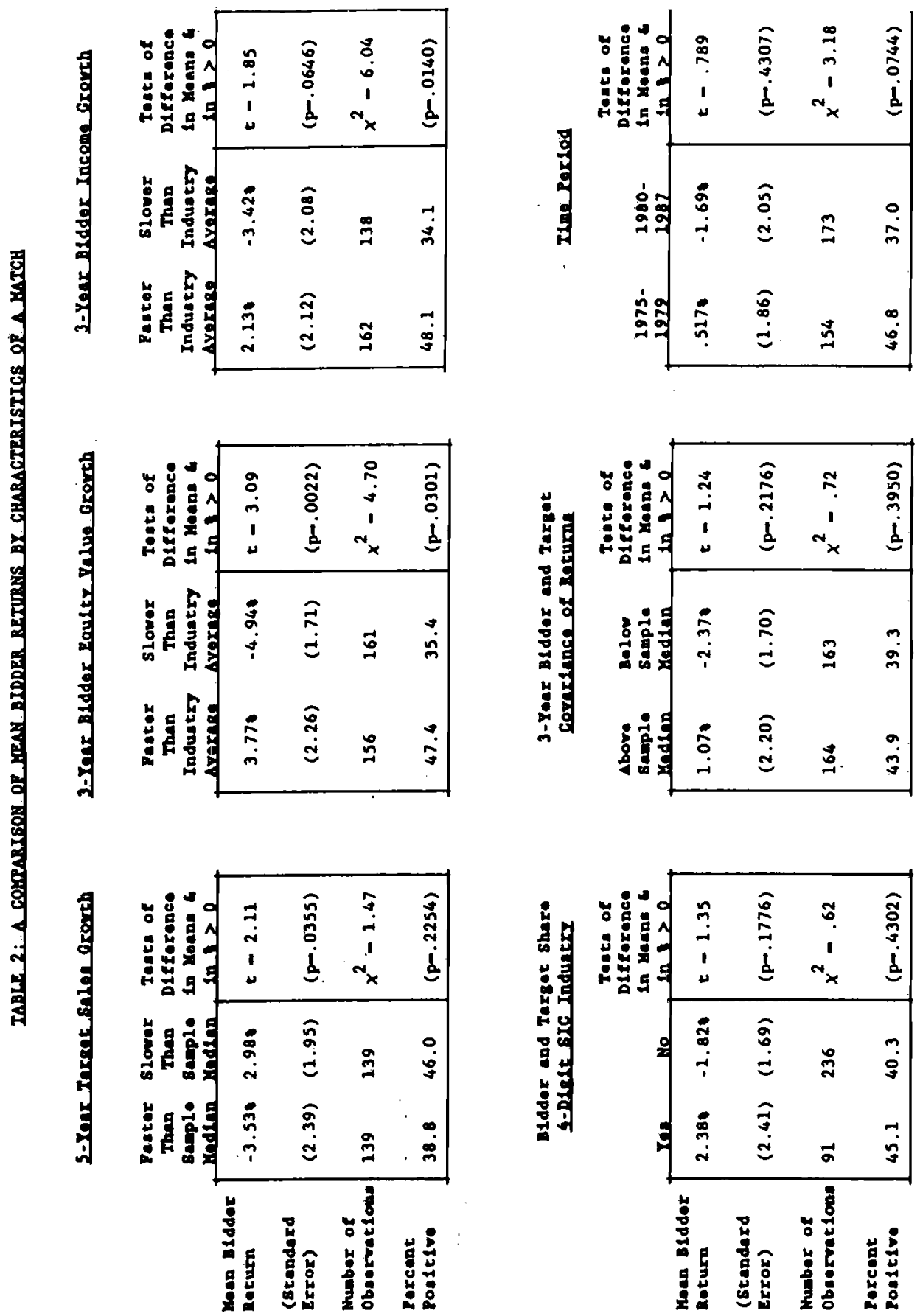
from making acquisitions. Moreover, they earn significantly less than do good managers. The return difference of 8.71 has a t-statistic of 3.09 .

A simflar result obtains using bidder's income growth relative to industry, except now we cannot as rellably conclude that firms underperforming their industries lose from making acquisitions. The difference between returns to good and bad managers from making an acquisition, at 5.558, is different from 0 with a p-value of 06 . Moreover, the fraction of returns that are positive is .481 for good managers, and only .341 for bad managers. This difference is significant with a p-value of .014. Bad managers actually lose on average when they make acquisitions, and those better at running their businesses are better at acquiring as well.

Our first measure of relatedness is defined above through commonality of 4-digit SIC industries that the target and the bidder operate in. The evidence in Table 2 shows that the average bidder return in a related acquisition is $2.388(2.41, .451>0)$, and in an unrelated acquisition it is $-1.828(1.69, .403>0)$. Although the two mean returns are of opposite signs and differ by 4.28 , they are not statistically significantly different from 0 or from each other. A similar picture emerges when we measure relatedness by correlation of bidder and target returns. The average bidder return in the subsample with above median correlation of bidder/target stock returns is 1.07 (2.20,.439>0) and that in the subsample with below median correlation is $-2.37 *(1.70, .393>0)$. The two mean returns are not significantly different from 0 or from each other.

The results become sharper when we distinguish between the 1970 s and the 1980s, as is done in Table 3. Table 3 shows that the difference between returns to related and unrelated acquisitions is both statistically and substantively more pronounced in the 1980s than in the 1970s. In Panel A of 
Table 3 we call an acquisition related if the target and the bidder operate in the same 4-digit SIC Industry. The panel shows that the returns to both related and unrelated acquisitions have changed from the 1970 s to the $1980 \mathrm{~s}$. The mean return to related acquisitions has risen (Insignificantly) by 1.38 In the 1980s, while the mean return to unrelated acquisitions has declined (also Insignificantly) by 4.28 . Note that the sharp decrease over time in the fraction of returns that are positive in unrelated acquisitions is statistically significant. This evidence indicates that unrelated diversification became quite unattractive in the 1980 s.

We can also see this point by comparing related to unrelated acquisitions in the two subperlods separately. Mean returns in related vs unrelated acquisitions are not statistically or substantively different in the 1970s, but are different in the 1980s. In the 1980s, the difference in mean returns in related and unrelated acquisitions is 6.81 , with a $t$ statistic of $1.57(\mathrm{p}-.12)$. During this perlod, in $45.6 \mathrm{z}$ of related acquisitions bidder returns are positive, but in only 32.8 of unrelated acquisitions are bidder returns positive $(p-.10)$. Not surprisingly, the rise In the relative attractiveness of related acquisitions has led to an increase In the fraction of acquisitions that are related, from 21 in the 1970 s to 338 In the 1980s.

These results are qualitatively confirmed using correlation of stock returns as a measure of relatedness, although the evidence is much weaker. One reason the results are weaker is that we split the sample at the median, and call acquisitions with above median stock return correlation related, even though according to our previous measure of relatedness over two thirds of the acquisitions are unrelated. The finding that the consequences of diversification are different in the two periods guides our regression 
TABLE 3: A COMPARISON OF RELATED AND UNRELATED ACOUISITIONS IN THE 1970, AND 1980,

PANEL A: DIVERSIFICATION MEASURED USING 4-DIGIT SIC INDUSTRIES THAT BIDDER AND TARGET OPERATE IN

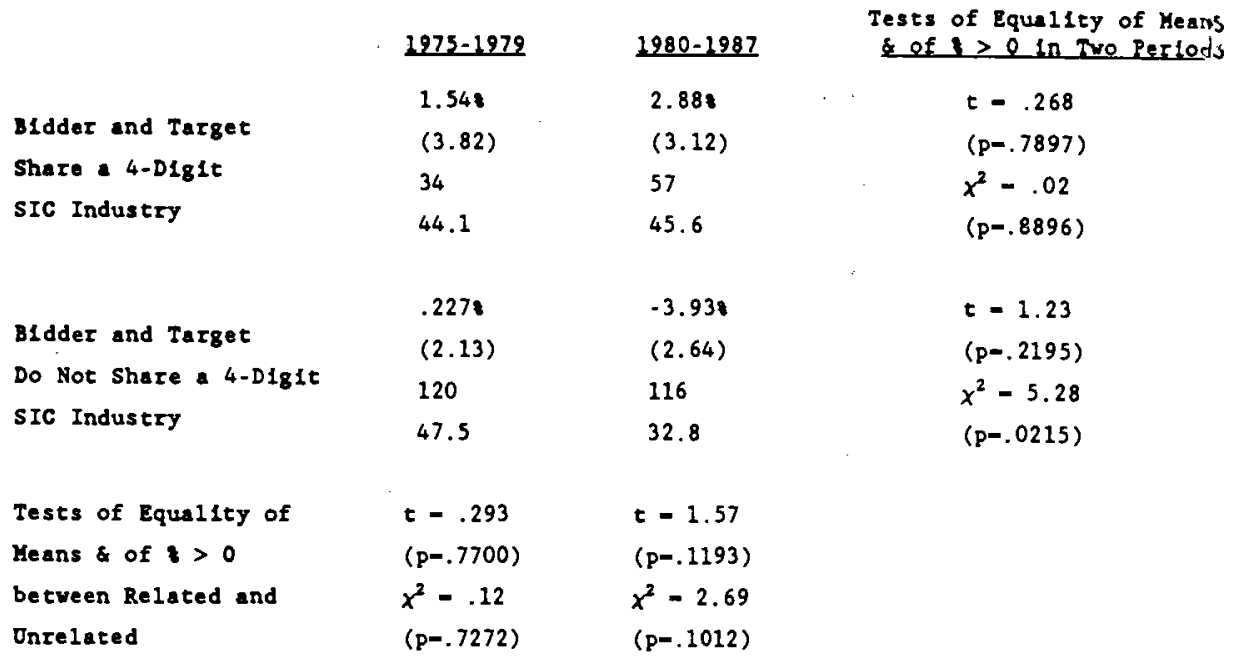

PANEL B: DIVERSIFICATION MEASURED USING CORRELATION COEFFICIENT OF BIDDER AND TARGET YONTHLY STOCK RETURNS OVER 3 YEARS PRIOR TO THE YEAR OF THE BID

\begin{tabular}{|c|c|c|c|}
\hline & $1975-1979$ & $1980-1987$ & $\begin{array}{l}\text { Tests of Equality of Heans } \\
\text { s of } i>0 \text { in Two Perlods }\end{array}$ \\
\hline Correlation of Bidder & .7708 & 1.458 & $t=.153$ \\
\hline and Target Stock & $(2.62)$ & $(3,78)$ & $(p=.8782)$ \\
\hline Returns above Sample & 93 & 71 & $x^{2}-.47$ \\
\hline Median & 46.2 & 40.8 & $(p-.4908)$ \\
\hline Correlation of Bidder & .1328 & -3.87 & $t=1.14$ \\
\hline and Target stock & $(2.47)$ & $(2.28)$ & $(p=.2558)$ \\
\hline Returns belov Sample & 61 & 102 & $x^{2}-2.78$ \\
\hline Median & 47.5 & 34.3 & $(p=.0955)$ \\
\hline $\begin{array}{l}\text { Tests of Equality of } \\
\text { Means of }>0 \\
\text { between Related and } \\
\text { Onrelated }\end{array}$ & $\begin{array}{l}t=.167 \\
(p-.8672) \\
x^{2}=.03 \\
(p-.8739)\end{array}$ & $\begin{array}{l}t-1.28 \\
(p-.2028) \\
x^{2}-.76 \\
(p-.3819)\end{array}$ & \\
\hline
\end{tabular}


analysis, In that we distingulsh between the 1970s and the 1980s in measuring the effect of diversification on returns to the bidding firms.

\section{Regressions.}

Table 4 presents the regressions of bidder returns on the characteristics of the match. The left panel of Table 4 uses 3-year bidder equity value growth relative to Industry as a measure of the quality of bidder management, and the right panel uses 3-year Income growth relative to 1ndustry. The three regressions on each side use commonality of 4 -digit industrles between the bidder and the target, correlation coefficient of bidder and target returns, and both of them at the same time as measures of relatedness. In all regressions, we use both a time dummy for the 1980 s and an interaction of that dumby with the relatedness measure to allow for different returns to diversification in the 1970s and the 1980s.

In all regressions, the coefficlent on the dummy equal to 1 when there are multiple bidders is highly signiflcant and is equal to about -.08. This means that entry by additional bidders reduces the winning bidder's market value by 8 cents on each dollar pald for the target.

Depending on the speciflcation, estimated bidder return falls between 10.08 and 11.7 as the target's change in $\log$ sales over the flve years prlor to the year of the acquisition goes from 0 to 1 . In all specifications, this estimate of the cost of buying growth is highly statistically significant. To Interpret the magnitude of this effect better, note that the value of 0 for the 5-year change in log sales represents 10th percentile sales growth performance, while the value of 1 represents 90 th percentlle performance. In our data, buylng rapidly growing firms is extremely costly to the bidders. 


\section{TABIE 4: REGRESSIONS OF BIDDER RETURN ON CHARACTERISTICS OF THE YATCH}

Quality of Bidder Management Measured by 3 -Year Equity Growth Relative co Induscry

\begin{tabular}{|c|c|c|c|c|c|c|}
\hline Varlable Name & $I$ & $I$ & III & $I$ & II & III \\
\hline Intercept & $\begin{array}{l}.095^{\circ} \\
(.035)\end{array}$ & $\begin{array}{l}.114^{b} \\
(.055)\end{array}$ & $\begin{array}{l}.120^{b} \\
(.055)\end{array}$ & $\begin{array}{l}.106^{\circ} \\
(.036)\end{array}$ & $\begin{array}{l}.117^{b} \\
(.056)\end{array}$ & $\begin{array}{l}.123^{\circ} \\
(.056)\end{array}$ \\
\hline $\begin{array}{l}\text { 5-Year Target Sales } \\
\text { Growth }\end{array}$ & $\begin{array}{l}. .100^{\circ} \\
(.033)\end{array}$ & $\begin{array}{l}-.100^{\circ} \\
(.033)\end{array}$ & $\begin{array}{l}-.107^{\circ} \\
(.034)\end{array}$ & $\begin{array}{l}. .115^{\circ} \\
(.035)\end{array}$ & $\begin{array}{l}. .110^{4} \\
(.035)\end{array}$ & $\begin{array}{l}. .117^{\circ} \\
(.035)\end{array}$ \\
\hline $\begin{array}{l}\text { Quality of Bidder } \\
\text { Management }\end{array}$ & $\begin{array}{l}.086^{\circ} \\
(.027)\end{array}$ & $\begin{array}{l}.091 \\
(.027)\end{array}$ & $\begin{array}{l}.086^{\star} \\
(.027)\end{array}$ & $\begin{array}{l}.064^{\circ} \\
(.026)\end{array}$ & $\begin{array}{l}.066^{\circ} \\
(.026)\end{array}$ & $\begin{array}{l}.064^{\mathrm{b}} \\
(.026)\end{array}$ \\
\hline $\begin{array}{l}\text { Duminy }=1 \text { if Deal Is } \\
\text { in } 1980.87\end{array}$ & $\begin{array}{l}-.077^{b} \\
(.036)\end{array}$ & $\begin{array}{l}-.137^{\mathrm{b}} \\
(.067)\end{array}$ & $\begin{array}{l}-.155^{\circ} \\
(.067)\end{array}$ & $\begin{array}{l}. .088^{b} \\
(.038)\end{array}$ & $\begin{array}{l}-.150^{\circ} \\
(.070)\end{array}$ & $\begin{array}{l}-.166^{b} \\
(.070)\end{array}$ \\
\hline $\begin{array}{l}\text { Dumy = } 1 \text { if Bidder } \\
\text { and Target Share a } \\
4-D 1 g i t \text { SIC Industry }\end{array}$ & $\begin{array}{l}-.029 \\
(.051)\end{array}$ & $\begin{array}{l}\cdots \\
\cdots\end{array}$ & $\begin{array}{l}-.025 \\
(.052)\end{array}$ & $\begin{array}{l}.027 \\
(.054)\end{array}$ & 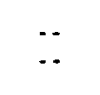 & $\begin{array}{l}-.025 \\
(.055)\end{array}$ \\
\hline $\begin{array}{l}\text { Dummy - } 1 \text { if Deal Is } \\
\text { in 1980-87 AND Target } \\
\text { and Bidder Share a } \\
\text { 4-Digit SIC Industry }\end{array}$ & $\begin{array}{l}.116^{\mathrm{e}} \\
(.070)\end{array}$ & 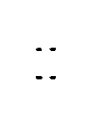 & $\begin{array}{l}.102 \\
(.071)\end{array}$ & $\begin{array}{l}.134^{\circ} \\
(.075)\end{array}$ & $\begin{array}{l}\cdots \\
\cdots\end{array}$ & $\begin{array}{l}.117 \\
(.076)\end{array}$ \\
\hline $\begin{array}{l}\text { Correl. Coeff. of } \\
\text { Bidder and Target } \\
\text { Monthly Stock Returns } \\
\text { over } 3 \text { Years Prior to } \\
\text { Takeover }\end{array}$ & -- & $\begin{array}{l}-.068 \\
(.119)\end{array}$ & $\begin{array}{l}-.053 \\
(.122)\end{array}$ & $\cdots$ & $\begin{array}{l}-.054 \\
(.122)\end{array}$ & $\begin{array}{l}=.038 \\
(.125)\end{array}$ \\
\hline $\begin{array}{l}\text { Dummy - } 1 \text { if Deal Is } \\
\text { In } 1980.87 \text { Times } \\
\text { Correl. Coeff. of } \\
\text { Bidder and Target } \\
\text { Stock Returns }\end{array}$ & $\begin{array}{l}\cdots \\
\cdots\end{array}$ & $\begin{array}{l}.275^{\circ} \\
(.160)\end{array}$ & $\begin{array}{l}.239 \\
(.162)\end{array}$ & $\cdots$ & $\begin{array}{l}300^{c} \\
(.172)\end{array}$ & $\begin{array}{l}.249 \\
(.174)\end{array}$ \\
\hline $\begin{array}{l}\text { Dummy - } 1 \text { if There Are } \\
\text { Multiple Bidders }\end{array}$ & $\begin{array}{l}.078^{b} \\
(.036)\end{array}$ & $\begin{array}{l}-.073^{\circ} \\
(.036)\end{array}$ & $\begin{array}{l}-.080^{\circ} \\
(.037)\end{array}$ & $\begin{array}{l}-.083^{\circ} \\
(.039)\end{array}$ & $\begin{array}{l}.077^{b} \\
(.039)\end{array}$ & $\begin{array}{l}-.086^{b} \\
(.039)\end{array}$ \\
\hline Number of Observations & 269 & 269 & 269 & 256 & 256 & 256 \\
\hline$R^{2}$ & .11 & .11 & .12 & .10 & .10 & .11 \\
\hline
\end{tabular}

'significant at 13 .

bignificant at 5s.

'significant at 10 .
Quallty of Bldder Management Measured by 3-Year Income Growth Relaclve to Industry 
Whether we measure past performance of the bidder by equity value growth relative to industry or by income growth relative to industry, its effect is very significant. When the industry-adjusted 3 -year change in the $\log$ of bidder equity value goes from 0 to 1 , the average return from making an acquisition rises by somewhere between 8.6 and 9.18 depending on the specification. An industry-adjusted change in the $\log$ of equity value of 0 represents median equity growth, while a value of 1 represents growth at the 95th percentile. The higher returns to bidders with faster industry-adjusted equity value growth are very significant.

Similarly, when the industry adjusted 3-year change in the bidder's log Income goes from 0 to 1 , the average return from making an acquisition rises by somewhere between 6.48 and 6.68 , depending on the specification. An industry-adjusted change in the $\log$ of income of 0 is about median, and a change of 1 is at about the 95 th percentile. Higher returns to bidders with higher income growth are again very significant.

As do the findings of Lang, Stulz and Walkling (1988), these results show that firms with better managers are also better acquirers. These results are inconsistent with a particular version of Roll's hubris hypothesis, in which managers of better performing firms are more arrogant and therefore overestimate the target's value under their control by more.

Comparing the effect of diversification on bidding firm's returns in the 1970 s and the 1980 s requires looking at three variables: the measure of relatedness, the time period dumy, and the interaction of the two. We do not discuss the regressions with both measures of relatedness included at the same time, since the strong correlation between the two measures makes the results insignificant and difficult to interpret. We also focus, for concreteness, on the left panel, where past bidder performance is measured by 
3-year equity value growth. The results for the right panel are very similar. Note finally that the correlation coefficient of stock returns can be intepreted similarly to the shared 4-digit SIC codes dumny. We can think of unrelated acquisitions as those for which the value of the correlation of stock returns is 0 , and of related acquisitions as those for which this correlation is 1 .

When the relatedness measure, the time period dummy, and the interaction are all equal to 0 , we are in the benchmark case of unrelated acquisitions in the 1970s. The coefficient on the 1980s dummy therefore captures the difference in returns on unrelated acquisitions between the 1980 s and the 1970s. In regression $I$, the return on unrelated acquisitions was 7.7 lower in the $1980 \mathrm{~s}$ than in the $1970 \mathrm{~s}(t=2.12)$. In regression II, the return from acquiring a target whose stock returns are uncorrelated with the bidder's was 13.7 lower in the $1980 \mathrm{~s}$ than in the 1970s $(t-2.05)$. Using the 0 correlation of stock returns to define unrelatedness yields bigger magnitudes simply because this is a more extreme form of unrelatedness than non-sharing of a 4-digit SIC industry. The results confirm our earlier finding that returns to unrelated acquisitions have declined substantially in the $1980 \mathrm{~s}$.

To see what happened to returns in related acquisitions between the 1970 s and the 1980s, we add the coefficient on the relatedness measure to the coefficient on the interaction between the relatedness measure and the 1980 s dummy. In regression $I$, the return on related acquisitions is $11.68-7.78-$ 3.98 higher in the 1980s than in the 1970s $(t-.66)$. In regression II, the return from acquiring a firm with a perfectly correlated stock return is $27.5 \%-13.7-13.8$ higher in the the $1980 \mathrm{~s}$ than in the $1970 \mathrm{~s}(t-1.30)$. In contrast to the statistically significant decline in returns to unrelated acquisitions over this period, the returns to related acquisitions have 
risen, but not significantly. The apparent overall decline of returns to acquisitions from the 1970 s to the 1980 s documented in Table 2 is completely a consequence of the large decline in returns to unrelated diversification. The coefficlent on the interaction of the 1980s dummy and the relatedness measure describes the change from the 1970s to the $1980 \mathrm{~s}$ of the returns difference in related and unrelated acquisitions. In regression $I$, the return from doing a related as opposed to an unrelated deal has gone up by 11.6 from the 1970 s to the 1980 s ( $t-1.67$, p-value -.097 ). In regression II, the return from buying a target whose stock returns are perfectly correlated with the bidder's rather than a target with uncorrelated stock returns has gone up by $27.58(t-1.72$, p-value -.087 ) from the 1970 s to the $1980 \mathrm{~s}$. In the $1980 \mathrm{~s}$, the penalty for diversification relative to making a related acquisition has gone way up.

similar results obtain when we use Industry-adjusted Income growth to measure past performance of the bidding f1rm. In the $1980 \mathrm{~s}$, returns to related acquisitions have gone (Insignificantly) up, returns to diversification have gone (significantly) down, and the cost of diversifying relative to buylng related has risen significantly. The overall verdict on diversification is clear: It is a bad 1dea in the 1980s.

The results in Table 4 support the proposition that managerlal objectives drive acquisitions. For example, they show that buying growth is a bad Idea from the point of view of bidding firm's shareholders. Of course, growth is one of the much discussed managerlal objectives, pursued elther for 1ts own sake or for the sake of assuring the survival of the bidding firm and the continulty of its top management.

The results in Table 4 also show that unrelated diversification is an extremely bad 1dea from the point of view of the bldding firm's shareholders 
In the 1980s. It is a bad Idea relative to doing nothing, and it is an even worse idea relative to making related acquisitions, that have become more attractive in the 1980s, perhaps because of the decline in antitrust enforcement. Like pursuit of growth, diversification can be understood as serving the objectives of managers.

Perhaps surprisingly, we do not find that diversification reduces bidding firms' shareholder wealth in the 1970s. We take this to mean one of two things. First, there might have been some efficiency reasons for diversification in the earlier period, such as imperfect capital markets or the attractiveness of conglomerate control. Second, the market might have favored diversification during this period given the information it had, even though ex post diversification proved unattractive and by the 1980 s the market caught on.

Finally, the results in Table 4 demonstrate that firms with bad managers (identified by poor firm performance relative to its industry) do worse in making acquisitions than firms with good managers. This result is consistent with the notion that bad managers have a greater personal incentive to acquire than do good managers, perhaps to find something they can do better and to avoid replacement. Indirectly, this finding also confirms the importance of managerial objectives in shaping acquisition strategies.

\section{Implications.}

Although this paper has focused on managerlal objectives in making mostly friendly acquisitions, the results may also shed Iight on the source of gains in hostile bust-up takeovers, leveraged buyouts, and defensive recapitalizations involving large scale divestitures. Our finding that in 
the 1980 s the stock market punishes unrelated diversification is consistent with the view that the source of bust-up gains in the 1980 s is the reversal of the unrelated diversification of the 1960s and the 1970s. Hostile bust-up takeovers simply undo past conglomeration.

At the same time, our finding that managerlal objectives drive bad acquisitions suggests a different interpretation of the gains from bustup takeovers. Raiders in these deals facilitate the sale of each plece of the target to the highest bidder. Part of the gain from this activity is doubtless the improvement in the operations of particular divisions under a more talented or a better motivated management team. But part of the gain from bustups may come from the willingness of other non-value-maximizing managers to buy the pleces of the target for their own empires. By allowing each buyer to overpay only for the piece of the target he really wants, the raider can collect more than any single bidder would pay for the whole target. This.suggests that takeover premia are likely to overestimate the efficlency gains from hostile bustup takeovers. 
References.

Amlhud, Yakov and Baruch Lev (1981), "Risk reduction as managerial motive for conglomerate mergers." Bel1 Journal of Economics 12, $605 \cdot 617$.

Asquith, Paul R., R.F. Brunner and David W. Mullins Jr. (1988), "Merger returns and the form of financing." Working paper.

Baumol, William J. (1959), Business Behavior, Value and Growth.

New York: Macmillan.

Bradley, Michael, A. Desal, and E. Han Kim (1988), "Synergistic gains from corporate acquisitions and their division between the stockholders of target and acquiring firms." Journal of Financlal Economics 21, 3-40.

Donaldson, Gordon (1984), Managing Corporate Wealth. New York: Praeger.

Donaldson, Gordon and Jay Lorsch (1983), Decision Making at the Top. New

York: Basic Books.

Dun and Bradstreet (1974 - 1987), M1110n Dollar Directory.

Ha11, Bronwyn H. (1988), "The effect of takeover activity on corporate research and development." in Alan J. Auerbach, ed., Corporate Takeovers: Causes and Consequences, Chicago: University Press.

Jarre11, Gregg, and Anette Poulsen (1988), "The returns to acquiring firms: evidence from three decades." Working paper.

Jensen, Michael C. (1986), "Agency cost of free cash flow, corporate finance, and takeovers." American Economic Review 76, $323-329$.

Lang, Larry, Rene M. Stulz, and Ralph A. Walkling (1988), "Tobin's $q$ and the gains from successful tender offers." Journal of Financlal Economics (forthcoming).

Lewellen, Wllbur, Claudlo Loderer and Ahron Rosenfeld (1985), "Merger decisions and executive stock ownership in acquiring firms." 
Journal of Accounting and Economics 7, $209-231$.

Mitchell, Mark L. and Kenneth Lehn (1988), "Do bad bidders become good targets?" Working paper.

Morck, Randall, Andrel Shleifer, and Robert W. Vishny (1989), "Alternative mechanisus for corporate control." American Economic Review (forthcoming).

Roll, Richard (1986), "The hubris hypothesis of corporate takeovers." Journal of Business 59, 197 - 216.

Servaes, Henri (1988), "Tobin's Q, agency costs and corporate control." Working paper.

Shleifer, Andrel and Robert W. Vishny (1988), "Managerial entrenchment: the case of manager-specific investments." Working paper.

Stulz, Rene M., Ralph A. Walkling and Moon H. Song (1988), "The distribution of target ownership and the division of gains in successful takeovers." Working Paper.

You, Victor L., Richard E. Caves, James S. Henry, and Michael M. Smith (1986), "Mergers and bidders' wealth: managerlal and strategic factors," in L.G. Thomas, ed. The Economics of Strateglc Planning, Boston: Lexington Books. 